\title{
Otentisitas Asuransi Syariah: Perspektif Hukum Islam dan UU No. 40 Tahun 2014 Tentang Perasuransian
}

\author{
Rully Syahrul Mucharom \\ (Fakultas Hukum Universitas Sultan Ageng Tirtayasa, \\ Jl. Raya Jakarta KM. 4 Pakupatan, Serang, Banten, 4211, Email : \\ rulymucharom@gmail.com)
}

\begin{abstract}
Abstrak:
Asuransi syariah (takâful) berdasar pada prinsip saling berbagi tanggung jawab. Berbagi tanggung jawab tersebut melalui premi yang dimiliki oleh masing-masing orang. Dalam prinsip hukum Islam, asuransi merupakan konsep saling membantu antara satu orang dengan yang lainnya tanpa ghurûr dan maysir. Prinsip berbagi tanggung jawab dalam asuransi syariah merupakan tolong menolong dengan dasar-dasar sistem sebagaimana telah ditentukan dalam alQur'an dan hadits. Asuransi syariah di Indonesia diatur bersamasama asuransi konvensional dalam Undang-undang No. 40 Tahun 2014 tentang perasuransian. Kondisi perundang-undangan tentang asuransi syariah yang diintegrasikan dengan asuransi konvensional merupakan kondisi yang tidak ideal mengingat perbedaan-perbedaan prinsipil di antara keduanya. Penerapan asuransi syariah (takâful) tidak semata-mata membutuhkan payung hukum tetapi juga aturan yang jelas dan khas. Selain membahas kedudukan asuransi syariah dalam Undang-undang No. 40 Tahun 2014 Tentang Perasuransian, kajian ini juga membahas asuransi dalam persepktif hukum Islam.
\end{abstract}

\section{Kata-kata Kunci:}

Otentisitas Asuransi Syariah, Undang-Undang No. 40 tahun 2014,

Wakalah, Hukum Islam

\begin{abstract}
:
Sharia insurance (takâful) is based on the principle of sharing responsibility. It is done through premiums owned by each party. In the Islamic law principle, insurance constitutes the concept of mutual help between one person and another without ghurûr (deceiving) and maysir (gambling). The principle of sharing responsibility in the sharia insurance is helping each other on the basis of a system as defined in the Qur'an and hadith. Sharia insurance in Indonesia as well as
\end{abstract}


conventional insurance are regulated in Law No. 40/2014 on insurance. The legislation of sharia insurance which is integrated with conventional insurance can be seen as a condition that is not ideal considering the principal differences between the two. The Implementation of sharia insurance (takâful) does not merely require a legal footing but also clear and specific rules. In addition to discussing the status of takâful in the Law no. 40 /2014 on insurance, this paper also discusses the insurance in the perspective of Islamic law.

\section{Key Words:}

Sharia Insurance Authenticity, Law Number 40 year 2014, Wakalah, Islamic Law

\section{Pendahuluan}

Islam diyakini sebagai agama universal, tidak terbatas ruang dan waktu sebagaimana dinyatakan oleh al-Qur'an sendiri. Dengan demikian, Islam seharusnya dapat diterima oleh setiap manusia, tanpa harus ada pertentangan dengan situasi dan kondisi di mana manusia itu berada. Islam dapat berhadapan dengan masyarakat modern, sebagaimana ia dapat berhadapan dengan masyarakat yang bersahaja. Ketika berhadapan dengan masyarkat modern dengan tantangan modernitasnya, Islam dituntut dapat menghadapi tantangan modernitas tersebut. ${ }^{1}$ Dalam era modereinitas saat ini, banyak prodak muamalat yang berkembang, seiring dengan itu, maka diperlukan adanya sandaran sebagai mar'ja dalam menentukan hukum suatu muamalat, seperti yang berkembang saat ini yaitu asuransi syariah (takâful).

Konsep takâful sebagai upaya untuk menjalankan syariat Islam yang pada masa moderen ini karena berkembangnya model muamalat. Menurut Muhammad Farouq Nabhan, ${ }^{2}$ dalam pengertian para fuqaha syariah adalah menetapkan norma-norma hukum untuk menata kehidupan manusia, baik dalam hubungannya dengan tuhan, maupun dengan umat manusia lainnya. Sejalan dengan hal ini, maka

1 Amir Mu'allim dan Yusdani, Konfigurasi Pemikiran Hukum Islam, (Yogyakarta: UII Press, 1999), 1, dalam Achmad Bahrur Rozi, Penerapan Syari'ah Di Negara Modern (Analisis Ijtihad Pemikiran Abdullahi Ahmed An-Na'im), Jurnal Al-Ihkam, (Vol. 10 No.2 Desember 2015), 372.

${ }^{2}$ Muhammad Farûq Nabhân, al-Madkhal li al-Tasyrî' al-Islâm, (Bairut: Libanon, Dar al Qalam: 1981), 11. Dalam Abdul Manan, Reformasi Hukum Islam di Indonesia, (Jakarta: Rajawali Press, 2005), 41. 
syariah itu mencakup aspek-aspek akidah, akhlak, dan amaliah. Namun demikian, istilah syariah itu terkadang berkonotasi dengan fiqih, yaitu norma-norma amaliah beserta implikasi kajiannnya. Secara umum, bahwa kajian dalam hukum Islam mengandung 2 (dua) bidang pokok, yaitu: ${ }^{3}$

1. Kajian tentang perangkat peraturan terperinci yang bersifat amaliyah dan harus dikuti oleh umat Islam dalam kehidupan beagama. Inilah yang secara sederhana disebut fiqh dengan segala lingkup pembahasannya.

2. Kajian tentang ketentuan serta cara dan usaha yang sistematis dalam memproduksi perangkat peraturan yang disebut dengan ushul fiqh. Dalam term lain dapat juga disebut sebagai "metedologi hukum Islam".

Yang termasuk dengan syariah, dalam pengertian etimologis adalah jalan yang harus ditempuh (oleh setiap umat Islam). Dalam arti teknis, syariah adalah seperangkat norma ilahi yang mengatur hubungan manusia dengan Allah, hubungan manusia dengan manusia lain dalam kehidupan sosial, hubungan manusia dengan benda dan alam lingkungan hidupnya. Norma ilahi mengatur tata kehidupan berupa:

1. Kaidah ibadah, dalam arti khusus atau disebut juga dengan kaidah ibadah murni, mengatur cara dan upacara hubungan langsung manusia dengan tuhannya; dan

2. Kaidah mumalah, yang mengatur hubungan manusia dengan manusia lain dan benda dalam masyarakat.4"Hukum asal dalam sebuah bentuk muamalah adalah boleh dilakukan kecuali ada dalil yang mengharamkannya". Maksud kaidah ini adalah bahwa setiap muamalah dan transaksi, pada dasarnya boleh, seperti jual beli, sewa menyewa, gadai, kerjasama (mudlârabah atau musyârakah), perwakilan, dan lain-lain, kecuali yang tegas-tegas diharamkan seperti mengakibatkan kemudaratan, tipuan, judi dan riba. ${ }^{5}$

\footnotetext{
${ }^{3}$ Alaiddin Koto, Filsafat Hukum Islam, (Jakarta: Rajawali Pres, 2013), 27.

4 Mohammad Daud Ali, Hukum Islam, Pengantar Ilmu Hukum dan Tata Hukum Islam di Indonesia, (Jakarta: Rajawali Pres, 2014), 34.

${ }^{5}$ Dewan Syariah Nasional (DSN) selalu menggunakan kaidah ini dalam keputusankeputusannya. Lihat Himpunan Fatwa DSN Edisi Kedua Tahun 2003, dalam H. A. Djazuli, Kaidah-Kaidah Fikih, Kaidah-Kaidah Hukum Islam dalam Menyelesaikan MasalahMasalah yang Praktis, (Jakarta: Kencana Prenadamedia Group, 2006), 130.
} 
Asuransi pada dasarnya adalah nilai-nilai kebaikan dengan sistem adanya penanggung dan tertanggung resiko, tetapi akad yang dibangun dalam asuransi tidak memasukan akad tabarru'6 sebagai dasar dalam upaya tolong menolong.

Pada prinsipnya, takâful adalah transaksi keuangan berdasarkan prinsip-prinsip kerjasama, tanggung jawab, jaminan, perlindungan dan bantuan antara kelompok peserta, yang mewakili bentuk asuransi mutual. Di bawah skema takâful, peserta takâful (juga dikenal sebagai pemegang polis asuransi) memberikan kontribusi proporsi tertentu dari jumlah penuh dari kontribusinya sebagai tabarru '. Sumbangan dari seluruh peserta diakumulasi ke dalam dana umum yang disebut dana tabarru' atau dana risiko, dari mana kompensasi atau ganti rugi diberikan kepada peserta menderita kerugian didefinisikan. Ini adalah kebijakan saling kerjasama, solidaritas dan persaudaraan terhadap risiko tak terduga atau bencana, di mana pihak yang terlibat, diharapkan dapat memberikan kontribusi benar. ${ }^{7}$

Ada dua jenis takâful yaitu; takâful asuransi jiwa (dikenal sebagai takâful keluarga) dan asuransi non-jiwa (dikenal sebagai takâful umum). asuransi non-jiwa takâful beroperasi cukup mirip dengan jaminan bersama dimana semua peserta berkontribusi saham mereka sendiri premi ke dalam kolam dan saling setuju untuk mengganti kerugian peserta yang menderita bahaya yang diasuransikan. asuransi jiwa takâful bekerja baik sebagai tabungan instrumen. Peserta menetapkan jumlah target mereka sendiri untuk mengumpulkan selama jangka waktu tertentu, serta alat perlindungan di mana semua

\footnotetext{
6 Pada dasarnya kalimat tabarru' adalah upaya untuk memberikan sesuatu kepada orang lain sebagai dasar saling tolong menolong, atau dapat diartikan sebagai hibah, oleh karena itu hal tersebut paling tidak memenuhi 4 (empat) rukun, antara lain:

1. Adanya yang memberi, syaratnya ialah orang yang berhak memperedarkan hartanya dan memiliki barang yang diberikan;

2. Ada yang diberi, syaratnya yaitu berhak memiliki;

3. Adanya ijab dan qabul; dan

4. Adanya barang yang diberikan.

Lihat Sulaiman Rasjid, Figh Islam, Cet Ke-39, (Bandung: Sinar Baru Algesindo, 2006), 327.

7 Mohamad Abdul Hamid, et. al. The Ownership of Islamic Insurance (Takaful) in Malaysia, International Journal of Advances in Management and Economics, (Vol.2, Issue 6, Nov.-Dec. 2013), 22.
}

$$
\text { al-1hikam Vol.12 No.1 Juni } 2017
$$


peserta menjamin satu sama lain terhadap peristiwa tertentu yang akan mengubah kondisi keuangan mereka. ${ }^{8}$

Di Indonesia, asuransi merupakan bagian dari kaidah muamalah yang dibangun atas dasar saling menanggung satu dengan yang lainnya. Upaya untuk menciptakan industri perasuransian yang lebih sehat, dapat diandalkan, amanah, dan kompetitif secara umum dilakukan, baik dengan penetapan ketentuan baru maupun dengan penyempurnaan ketentuan yang telah ada. Upaya tersebut diwujudkan antara lain dalam bentuk, sebagai berikut: ${ }^{9}$

1. Penetapan landasan hukum bagi penyelenggaraan usaha asuransi syariah dan usaha reasuransi syariah;

2. Penetapan status badan hukum bagi perusahaan asuransi berbentuk usaha bersama yang telah ada pada saat undangundang ini diundangkan;

3. Penyempurnaan pengaturan mengenai kepemilikan perusahaan perasuransian yang mendukung kepentingan nasional;

4. Pemberian amanat lebih besar kepada perusahaan asuransi dan perusahaan asuransi syariah untuk mengelola kerja sama dengan pihak lain dalam rangka pemasaran layanan jasa asuransi dan asuransi syariah, termasuk kerja sama keagenan; dan

5. Penyempurnaan ketentuan mengenai kewajiban untuk menjaga tata kelola perusahaan yang baik, kesehatan keuangan, dan perilaku usaha yang sehat.

Dengan adanya UU No. 40 Tahun 2014 tentang Perasuransian pada dasarnya mendorong pembangunan nasional melalui 2 (dua) pendekatan pembangunan perasurasian yaitu asuransi konvensional dan asuransi syariah dalam satu prodak peraturan perundangundangan.

Kedudukan Asuransi Syariah Pasca Berlakunya Undang-undang No. 40 Tahun 2014 tentang Perasuransian

Seiring dengan perkembangan zaman, masyarakat dan kemajuan ilmu pengetahuan serta teknologi, berbagai masalah hukum muncul ke permukaan di tengah-tengah masyarakat dewasa

8 Ibid., 22.

${ }^{9}$ Lihat Penjelasan UU No. 40 Tahun 2014 tentang Perasuransian. 
ini, dimana masa lalu tidak ada, atau sudah ada tetapi belum berevolusi, kini bermunculan bak jamur di musim hujan, yang selanjutnya menuntut jawaban dari segi hukum, yaitu syariah dan fikih di mana pada saat ini sebagian Muslim itu sendiri telah beranggapan, bahwa syariat Islam yang bersumber dari al-Qur'an dan Sunah Rasulullah, sebagiannya sudah tidak relevan lagi dengan kondisi sekarang ini dan banyak permasalahan yang aktual bermunculan, belum diayomi oleh Alquran dan Sunnah Rasul tersebut. Sebenarnya semua masalah aktual dapat diselesaikan dan ditetapkan hukumnya dengan syariat Islam, yaitu dengan Alquran dan Sunnah Rasulullah, atau dengan fikih, karena fikih itu sendiri adalah penampakan pemahaman dan interpretasi dari nash-nash alQuran dan Sunah melalui ijtihad.

Berikut ini akan dibahas beberapa permasalahan, atau kasus aktual yang dapat ditetapkan dan diselesaikan hukumnya berdasarkan syariat dan fikih, yang keduanya ini populer disebut dengan hukum Islam. ${ }^{10}$

Dalam perkembangan hukum asuransi di Indonesia, secara umum yang telah diatur dalam UU No. 40 Tahun 2014 Tentang Perasuransian, merupakan aturan yang secara umum mengatur 2 (dua) objek asuransi, dimana asuransi konvensional dan asuransi syariah. Jika dikaji dari persepepektif aplikatif, maka asuransi konvensional harus memenuhi syarat-syarat yang harus dipenuhi, sebagai berikut:

1. Kesepakatan (Consensus)

Tertanggung dan penanggung sepakat mengadakan perjanjian asuransi. Kesepakatn tersebut meliputi: ${ }^{11}$

a. Benda yang menjadi objek asuransi;

b. Pengalihan resiko dan pembayaran premi;

c. Evenemen dan anti rugi;

d. Syarat-syarat khusus asuransi; dan

e. Dibuat secara tertulis yang disebut polis.

10 Abdul Wahab Abd. Muhaimin, Aktualisasi Syariah Dan Fikih Dalam Menyelesaikan Pelbagai Persoalan Hukum, Jurnal Ahkam (Vol. XV, No. 2, Juli 2015), 241.

11 Abdulkadir Muhammad, Hukum Asuransi Indonesia, (Bandung: Citra Aditya Bakti, 2006), 50-52. 
Pengadaan perjanjian antara penanggung dan tertanggung dapat dilaksanakan secara langsung atau tidak langsung.

2. Kewenangan (Authority)

Kedua pihak penanggung dan tertanggung berwenang melakukan perbuatan hukum yang diakui oleh undangundang. Kewenangan tersebut yang bersifat subjektif dan bersifat objekif.

3. Objek Tertentu (Fixed Object)

Objek tertentu dalam perjanjian asuransi adalah objek yang diasuransikan, dapat berupa harta kekayaan dan kepentingan yang melekat pada harta kekayaan, dapat pula berupa jiwa dan raga manusia.

4. Kausa yang halal (Legal Cause)

Kausa yang halal maksudnya adalah isi perjanjian itu tidak dilarang undang-undang, tidak bertentangan dengan ketertiban umum, dan tidak bertentangan dengan kesusilaan.

Syarat-syarat tersebut harus ada dalam ketentuan perjanjian perasuransian yang dilaksanakan secara bersama-sama oleh penanggung dan tertanggung dalam perjanjian asuransi yang dibuat oleh kedua belah pihak tersebut, sehingga tidak ada yang dirugikan.

Dalam asuransi, pada umumnya dianggap sebagai pengalihan resiko atau pembagian resiko, apabila terjadi sebagai berikut: ${ }^{12}$

1. Resiko yang benar-benar menjadi kenyataan itu oleh penangung yang sama disebarkan atau dibagi-bagikan menjadi beban bagi para tertanggungnya. Ini mungkin dilaksanakan karena tidaklah selalu bahwa resiko itu menjadi suatu kenyataan pada waktu yang bersamaan pada setiap tertanggung, sehingga memungkinkan resiko dari orang

12 Djoko Prakoso, Hukum Asuransi Indonesia, (Jakarta: Rineka Cipta, 2004), 18. Secara umum, bahwa resiko dapat dikalsifikasikan sebagai berikut:

1. Speculative risks, yaitu resiko yang bersifat spekulatif yang bias mendatangkan rugi atau laba. Misalnya seorang pedagang bias untung atau rugi dalam usahanya.

2. Pure risks, yaitu resiko yang selalu menyebabkan kerugian. Perusahaan asuransi beroprasi dalam bidang pure risks (kematian, kapal tengelam, kebakaran, dan sebagainya).

Lihat pada Abbas Salim, Asuransi dan Manajemen Risiko, (Jakarta: Rajawali Press, 2005), 4 . 
tertanggung ditanggung secara bersama oleh semua tertanggung lainnya;

2. Oleh karena resiko yang dialihkan kepada penangunggung itu sangat besar sehingga penanggung itu secara sendiri tidak mampu menanggungnya, dank arena itu membagi-bagi resiko itu dengan penanggung lain; dan

3. Juga dapat terjadi pembagian atau penyebaran resiko ini dengan herverzekering yaitu bahwa penanggung mempertanggungkan tanggung jawabnya atas resiko yang diterimannya kepada penanggung lain.

Pengalihan resiko yang dilakukan dalam asuransi konvensional pada dasarnya menjadikan pembeda dengan sistem asuransi syraiah, dimana dalam sistem asuransi syariah tidak hanya menitikberatkan kepada tijârî yang pada dasarnya penjualan polis yang berakhir kepada pengalihan resiko yang dilakuakn oleh perusahaan asuransi, tetapi melakukan transformasi dari model tijârî kepada tabarru' sebagai upaya saling membagi satu sama lainnya, sehingga tidak tertumpu kepada pengalihan resiko semata.

Asuransi syariah merupakan bagian dari bisnis syariah, oleh karena itu sebagai bagian dari bisnis yang berbasiskan syariah, maka harus berlandaskan kepada etika, Menurut Yûsuf Qardlâwi, Islam mempunyai etika berbisinis, antara lain:13

1. Menegakkan larangan memperdagangkan barang-barang yang diharamkan;

2. Bersikap benar, amanah dan jujur;

3. Menegakan keadilan dan mengharamkan riba (bunga);

4. Menerapkan kasih sayang dan mengharamkan monopoli;

5. Menegakan toleransi dan persaudaraan; dan

6. Berpegang pada prinsip bahwa perdagangan adalah bekal menuju akhirat.

Sebagai bagian dari bisnis syariah, asuransi syariah harus mendasarkan kepada etika bisnis Islam, dimana yang menjadi petimbangan utama dalam bisnis asuransi syariah harus didasarkan

13 Yusuf Qardhawi, Norma dan Etika Ekonomi Islam, (Jakarta: Gema Insani Press, 2011), 173, dalam Mardani, Hukum Bisnis Syariah, (Jakarta: Kencana Prenadamedia, 2014), 27. 
kepada objek yang bersifat tidak diharamkan oleh Allah sehingga dengan objek yang tidak diharamkan oleh Allah, mendorong akad yang dijalankan dalam asuransi syariah melahirkan akad tarâdhi di antara para pihak yang melakukannya.

Ruang lingkup usaha asuransi dalam usaha perasuransian syariah dan perasuransian konvensional secara umum dibedakan, di mana perusahaan asuransi umum hanya dapat menyelenggarakan sebagai berikut:

1. Usaha asuransi umum, termasuk lini usaha asuransi kesehatan dan lini usaha asuransi kecelakaan diri; dan

2. Usaha reasuransi untuk risiko perusahaan asuransi umum lain. Perusahaan asuransi jiwa hanya dapat menyelenggarakan usaha asuransi jiwa termasuk lini usaha anuitas, lini usaha asuransi kesehatan, dan lini usaha asuransi kecelakaan diri.

Perusahaan reasuransi hanya dapat menyelenggarakan usaha reasuransi. Sedangkan perusahaan asuransi umum syariah hanya dapat menyelenggarakan, sebagai berikut:

1. Usaha asuransi umum syariah, termasuk lini usaha asuransi kesehatan berdasarkan prinsip syariah dan lini usaha asuransi kecelakaan diri berdasarkan prinsip syariah; dan

2. Usaha reasuransi syariah untuk risiko perusahaan asuransi umum syariah lain.

Perusahaan asuransi jiwa syariah hanya dapat menyelenggarakan usaha asuransi jiwa syariah termasuk lini usaha anuitas berdasarkan prinsip syariah, lini usaha asuransi kesehatan berdasarkan prinsip syariah, dan lini usaha asuransi kecelakaan diri berdasarkan prinsip syariah. Perusahaan reasuransi syariah hanya dapat menyelenggarakan usaha reasuransi syariah.

Penyelenggaraan asuransi di Indonesia secara umum, baik itu pada asuransi syraiah atau pada asuransi konvensional, dimana berdasarkan Pasal 25 UU No. 40 Tahun 2014 tentang Perasuransian, dimana objek asuransi di Indonesia hanya dapat diasuransikan pada perusahaan asuransi dan perusahaan asuransi syariah yang mendapatkan izin usaha dari Otoritas Jasa Keuangan, kecuali dalam hal, sebagai berikut:

1. tidak ada perusahaan asuransi dan perusahaan asuransi syariah di Indonesia, baik secara sendiri-sendiri maupun bersama-sama, 
yang memiliki kemampuan menahan atau mengelola risiko asuransi atau risiko asuransi syariah dari objek asuransi yang bersangkutan; atau

2. Tidak ada perusahaan asuransi dan perusahaan asuransi syariah di Indonesia yang bersedia melakukan penutupan asuransi atau asuransi syariah atas objek asuransi yang bersangkutan. Ketentuan tersebut, menggambarkan bahwa yang menjadi objek asuransi syariah dan asuransi konvensional menjadi sama.

Selain itu, Pasal 26 ayat (1) Perusahaan perasuransian wajib memenuhi standar perilaku usaha yang mencakup ketentuan mengenai, sebagai berikut: a. polis; b. premi atau kontribusi; c. underwriting dan pengenalan pemegang polis, tertanggung, atau peserta; $d$. penyelesaian klaim; e. keahlian di bidang perasuransian; $f$. distribusi atau pemasaran produk; g. penanganan keluhan pemegang polis, tertanggung, atau peserta; dan $h$. standar lain yang berhubungan dengan penyelenggaraan usaha. Dengan standarstandar yang sama, ketentuan undang-undang tersebut memposisikan otensitas hukum asuransi syariah dan asuransi konvensional sama.

Otensitas Asuransi Syariah (Takâful) Dalam Persepktif Hukum Islam dan Fatwa Dewan Syariah Nasional (DSN) No: 21/DSNMUI/X/2001 Tentang Pedoman Umum Asuransi Syari'ah

Perkembangan asuransi syariah sebagai kebutuhan umat Islam pada umumnya dalam menjalankan syariat Islam dalam bidang muamalat yang pada abad moderen ini berkembang. Menurut Ahmad Azhar Basir, bahwa asuransi syariah didasarkan kepada 2 (dua) konsep utama, pertama, takâful saling menanggung resiko diantara para pesertanya, yang didalamnya ditegakan prinsip-prinsip saling bertanggung jawab, bekerja sama, atau bantu membantu, serta melindungi penderitaan satu dengan yang lainnya. Ketiga prinsip ini dasarnya adalah ibadah yang wujudnya adalah tabarru'. Kedua, adalah menganut konsep mudlârabah, yakni bagi hasil dari keuntungan yang diperoleh dari pengembangan dana asuransi para pserta. Adapun perusahaan asuransi atau takâful menerima amanah dari peserta untuk melaksanakan kesepakatan saling menanggung atas resiko 
yang diderita oleh peserta. Dengan prinsip ini, maka berbagai keberatan yang dihadapkan kepada asuransi syariah menjadi tidak ada. Begitu pula ketidakpastian (al-gharâr), perjudian (al-maysir), dan riba, akan hilang sendirinya. ${ }^{14}$ Oleh karena itu, diperlukan al-ikhtiyât, dalam menjalankan asuransi syariah, sehingga prinsip dasar syariah dapat dijalankan dealam muamalat asuransi syariah.

Secara umum, bahwa akad yang menjadi bagian yang penting dalam asuransi syariah untuk menjadikan kejelasan ikatan yang dibuat oleh para pihak dalam menjalankan asuransi syariah tersebut. Dikaji secara umum, bahwa dalam asuransi syariah dapat dimasukan dalam dua akad, antara lain: ${ }^{15}$

\begin{tabular}{|c|c|}
\hline Akad Tabarru' & Akad Tijâri \\
\hline $\begin{array}{l}\text { 1. Bertujuan saling membantu } \\
\text { sesame (saling menolong); } \\
\text { 2. Akad dapat dilakukan satu } \\
\text { pihak; } \\
\text { 3. Jenis akad tabarru' tidak dapat } \\
\text { dirubah dengan jenis akad } \\
\text { tijari; } \\
\text { 4. Akad tabarru' diniatkan untuk } \\
\text { kebaikan dan kemaslahatan; } \\
\text { dan } \\
\text { 5. Berdimensi dunia akhirat. }\end{array}$ & $\begin{array}{l}\text { 1. Bertujuan komersil; } \\
\text { 2. Akad harus dilakukan minimal } 2 \\
\text { (dua) pihak; } \\
\text { 3. Jenis akad tijârî dapat diubah } \\
\text { menjadi jenis akad tabarru' jika } \\
\text { pihak yang tertahan haknya, } \\
\text { dengan rela melepaskan haknya } \\
\text { sehingga menggugurkan } \\
\text { kewajiban pihak yang belum } \\
\text { menunaikan kewajibannya; } \\
\text { 4. Belum tentu dinitakan untuk } \\
\text { kebaikan dan kemaslahatan, } \\
\text { bergantung kepada niat pihak } \\
\text { yang berakad; dan } \\
\text { 5. Bisa berdimensi dunia saja. }\end{array}$ \\
\hline
\end{tabular}

Model takâful Ada berbagai model yang diadopsi di negaranegara muslim yang berbeda, satu model mudlarabah model yang menggambarkan bahwa semua pemegang polis harus setuju untuk berbagi keuntungan (atau kerugian) dari usaha tersebut. ${ }^{16}$ Dengan

14 Abdul Rahman Ghazaly, et. al. Fiqh Muamalat, (Jakarta: Kencana Prenadan Media Group, 2010), 242-243.

15 Agus Edi Sumanto, et.al. Solusi Asuransi, Lebih Indah dengan Syariah, (Bandung: Salamadani, 2009), 70.

16 Maysami, R. C., Golriz, H. and Hedayati, Pragmatic Interest-free Banking: Metamorphosis of the Iranian Financial System. (Journal of International Banking Law, 
model ini, operator tidak perlu membayar komisi tetapi akan menerima gaji yang akan dibayarkan dari bagian laba yang dilakukan oleh perusahaan. Kondisi yang sama berlaku untuk manajemen. ${ }^{17}$ Pembagian laba rugi antara peserta dan operator yang ditentukan di muka dan dinilai atas dasar tahap perkembangan perusahaan dan pendapatan. Nisbah bagi disetujui oleh komite syariah secara muka. Biasanya jumlah beban dibebankan kepada pemegang saham di bawah mudlârabah.

Model kedua adalah wakâlah model. Model ini menjelaskan bahwa surplus investasi dana pemegang polis - bersih dari fee atau biaya manajemen pergi ke pemegang polis. peserta membayar biaya wakâlah dari kontribusi yang menutupi biaya operator yang total gaji bisnis dan operator. Biaya wakâlah ditentukan oleh Syariah Dewan Penasehat dari perusahaan satu dasar tahun sebelumnya. Untuk memberikan insentif kepada operator untuk pemerintahan yang baik, biaya manajemen dibayarkan sesuai tingkat kinerja. ${ }^{18}$

Model ketiga adalah wakâlah waqf model. Menurut model ini, dana wakaf dibuat sebagai badan hukum yang terpisah dengan kontribusi dari jumlah peserta dan jumlah deposit untuk dana ini dianggap sebagai "tabarru'" sumbangan. Tujuan dari dana ini adalah untuk memberikan bantuan kepada peserta terhadap risiko didefinisikan sesuai dengan syarat dan kondisi dari dana wakaf. ${ }^{19}$

Dalam rangka menjalankan asuransi syariah, di mana prinsipprinsip kebersamaan dan kerjasama harus menjadi dasar untuk asuransi dalam Islam. Unsur-unsur tanggung jawab bersama, ganti rugi bersama, kepentingan bersama, solidaritas dan sebagainya diwujudkan dalam sistem takâful karena dasar prinsip-prinsip ini. Konsep asuransi ini dapat diterima dalam Islam karena:

1. Kerjasama antara peserta untuk kebaikan bersama mereka.

12, 1997), 92-108, dalam Mher Mushtaq Hussain dan Ahmad Tisman Pasha, Conceptual And Operational Differences Between General Takaful And Conventional Insurance, Australian Journal of Business and Management Research (Vol.1 No.8, November-2011), 24.

17 Billah, M. M. (1996). Comment on Sheikh Al-Azhar's Fatwa against life insurance. New Horizon, 58, 3-6, dalam Mher Mushtaq Hussain dan Ahmad Tisman Pasha, Ibid., 24.

18 Ibid., 24.

19 Ibid., 24. 
2. Pembayaran kontribusi oleh masing-masing peserta dalam membantu setiap sesama anggota yang membutuhkan.

3. Kontribusinya dianggap sumbangan (tabarru') kepada anggota dalam kelompok.

4. Kerugian dibagi dan kewajiban tersebar merata sesuai dengan sistem komunitas pooling dari kontribusi.

5. Ketidakpastian telah dieliminasi sebagai istilah dalam kontribusi dan kompensasi yang dibuat jelas kepada peserta.

6. Keuntungan Berasal pada biaya orang lain bukan tujuan dari sistem. ${ }^{20}$

Oleh karena itu konsep asuransi itu sendiri tidak bertentangan dengan semangat syariah. Bahkan, mitigasi risiko dengan mengadopsi hukum bilangan besar secara luas digunakan, terutama dalam praktek aqila seperti yang disebutkan. Firman Allah dalam Q.S:
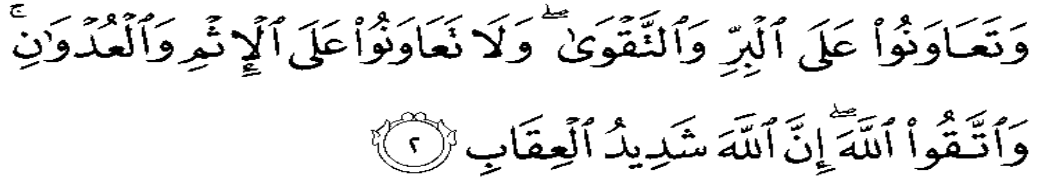

"Tolong menolonglah kamu sekalian dan kebaikan dan ketakwaan, dan janganlah tolong menolong kamu sekalian dalam dosa dan permusuhan, bertaqwalah kepada Allah, sesungguhnya Allah seberat-berat hukumannya."

Dalam upaya untuk melaksanakan prinsip-prinsip asuransi syariah sesuai dengan ketentuan hukum Islam, Dewan Syariah Nasional yang merupakan lembaga yang memberikan fatwa dalam muamalah yang dilaksanakan di Indonesia, dimana berbasiskan nilai-nilai syariah, dimana melalui ketentuan pada Fatwa Dewan Syariah Nasional No. 21/DSN-MUI/X/2001 tentang Pedoman Umum Asuransi Syari'ah, sebagai berikut:

Pertama: ketentuan umum, sebagai berikut: 1). Asuransi Syariah (ta'mîn, takâful, atau tadlâmun) adalah usaha saling melindungi dan tolong-menolong di antara sejumlah orang/pihak melalui investasi dalam bentuk aset dan/atau tabarru' yang memberikan pola

20 Suria Zainuddin dan Izyan Nadiah Md Noh, An overview of the emergence of Takaful: An Islamic type of insurance policy, International Journal of Business and Economics $\begin{array}{llll}\text { Research 2013; } & \text { 2(5), hlm. }\end{array}$ http://repository.um.edu.my/31924/1/10.11648.j.ijber.20130205.13.pdf. $\quad$ (Diakses pada tanggal 12 September 2016). 
pengembalian untuk menghadapi resiko tertentu melalui akad (perikatan) yang sesuai dengan syariah; 2). Akad yang sesuai dengan syariah yang dimaksud pada point (1) adalah yang tidak mengandung gharâr (penipuan), maysir (perjudian), riba, zhulm (penganiayaan), risywah (suap), barang haram dan maksiat; 3). Akad tijârah adalah semua bentuk akad yang dilakukan untuk tujuan komersial; 4. Akad tabarru' adalah semua bentuk akad yang dilakukan dengan tujuan kebajikan dan tolong-menolong, bukan semata untuk tujuan komersial; 5). Premi adalah kewajiban peserta Asuransi untuk memberikan sejumlah dana kepada perusahaan asuransi sesuai dengan kesepakatan dalam akad; dan 6). Klaim adalah hak peserta asuransi yang wajib diberikan oleh perusahaan asuransi sesuai dengan kesepakatan dalam akad.

Kedua: akad dalam asuransi pada asuransi syariah sebagai berikut: 1) Akad yang dilakukan antara peserta dengan perusahaan terdiri atas akad tijârah dan/atau akad tabarru'; 2). Akad tijârah tersebut adalah mudlârabah, sedangkan akad tabarru' adalah hibah; dan 3). Dalam akad, sekurang-kurangnya harus disebutkan : a. hak \& kewajiban peserta dan perusahaan; b. cara dan waktu pembayaran premi; c. jenis akad tijârah dan/atau akad tabarru' serta syarat-syarat yang disepakati, sesuai dengan jenis asuransi yang diakadkan.

Ketiga: Kedudukan para pihak dalam akad tijarah dan tabarru', dalam perasuransian syariah, sebagai berikut: 1). Dalam akad tijarah (mudlârabah), perusahaan bertindak sebagai mudlârib (pengelola) dan peserta bertindak sebagai shâhib al-mâl (pemegang polis); dan 2). Dalam akad tabarru' (hibah), peserta memberikan hibah yang akan digunakan untuk menolong peserta lain yang terkena musibah. Sedangkan perusahaan bertindak sebagai pengelola dana hibah.

Keempat: Ketentuan dalam akad tijârah dan tabarru', dapat diklasifikasikan berdasarkan fatwa DSN tentang asuransi syariah sebagai berikut: 1). Jenis akad tijârah dapat diubah menjadi jenis akad tabarru' bila pihak yang tertahan haknya, dengan rela melepaskan haknya sehingga menggugurkan kewajiban pihak yang belum menunaikan kewajibannya; dan 2). Jenis akad tabarru' tidak dapat diubah menjadi jenis akad tijârah.

Kelima: Secara umum, Fatwa DSN, dapat dilihat bahwa jenis asuransi dan akadnya, sebagai berikut: 1). Dipandang dari segi jenis asuransi itu terdiri atas asuransi kerugian dan asuransi jiwa; dan 2). 
Sedangkan akad bagi kedua jenis asuransi tersebut adalah mudlârabah dan hibah.

Keenam: Dalam menentukan premi, berdasarkan Fatwa DSN, maka dapat dilakukan dalam bentuk sebagai berikut: 1). Pembayaran premi didasarkan atas jenis akad tijarah dan jenis akad tabarru'; 2). Untuk menentukan besarnya premi perusahaan asuransi syariah dapat menggunakan rujukan, misalnya tabel mortalita untuk asuransi jiwa dan tabel morbidita untuk asuransi kesehatan, dengan syarat tidak memasukkan unsur riba dalam penghitungannya. 3). Premi yang berasal dari jenis akad mudlârabah dapat diinvestasikan dan hasil investasinya dibagi-hasilkan kepada peserta; dan ). Premi yang berasal dari jenis akad tabarru' dapat diinvestasikan.

Ketujuh: Dalam asuransi syariah, berdasarkan kepada fatwa DSN, maka Klaim dapat dilakukan sebagai berikut: 1). Klaim dibayarkan berdasarkan akad yang disepakati pada awal perjanjian; 2). Klaim dapat berbeda dalam jumlah, sesuai dengan premi yang dibayarkan; 3). Klaim atas akad tijârah sepenuhnya merupakan hak peserta, dan merupakan kewajiban perusahaan untuk memenuhinya; dan 4). Klaim atas akad tabarru', merupakan hak peserta dan merupakan kewajiban perusahaan, sebatas yang disepakati dalam akad.

Kedelapan: Investasi yang dilakukan dapat berupa, sebagai berikut: 1). Perusahaan selaku pemegang amanah wajib melakukan investasi dari dana yang terkumpul; dan 2). Investasi wajib dilakukan sesuai dengan syariah.

Kesembilan: Reasuransi asuransi syariah hanya dapat melakukan reasuransi kepada perusahaan reasuransi yang berlandaskan prinsip syari'ah.

Kesepuluh: Pengelolaan asuransi syariah harus dalam bentuk, sebagai berikut: 1). Pengelolaan asuransi syariah hanya boleh dilakukan oleh suatu lembaga yang berfungsi sebagai pemegang amanah; 2). Perusahaan asuransi syariah memperoleh bagi hasil dari pengelolaan dana yang terkumpul atas dasar akad tijârah (mudlârabah); dan 3. Perusahaan asuransi syariah memperoleh ujrah (fee) dari pengelolaan dana akad tabarru' (hibah).

Kesebelas: Dalam upaya untuk memperkuat usaha asuransi syariah, ditambahkan ketentuan tambahan fatwa DSN tentang asuransi syariah, sebagai berikut: 1). Implementasi dari fatwa ini 
harus selalu dikonsultasikan dan diawasi oleh DPS (Dewan Pengawas Syariah); dan 2). Jika salah satu pihak tidak menunaikan kewajibannya atau jika terjadi perselisihan di antara para pihak, maka penyelesaiannya dilakukan melalui Badan Arbitrasi Syari'ah setelah tidak tercapai kesepakatan melalui musyawarah.

Dalam pandangan Yusof M.F mengutip sejumlah alasan yang mempengaruhi desain dan persembahan bisnis takâful pada umumnya, sebagai berikut:

1. Umat Islam merasa perlu untuk menerapkan Islam dan menerapkan aturan dan peraturan dalam total;

2. Umat Islam menginginkan sistem keuangan yang mampu menciptakan ekonomi yang benar-benar Islam demi umat;

3. Dengan pembentukan sistem perbankan Islam kebutuhan yang melekat muncul untuk asuransi takâful atau islami untuk layanan dan penawaran. Itu adalah bukti sejarah yang menyebabkan para ahli hukum Islam mengakui bahwa dasar dari tanggung jawab bersama dalam sistem "aqilah", meletakkan dasar asuransi mutual, dan secara umum menyimpulkan bahwa asuransi dalam Islam harus didasarkan pada prinsip-prinsip kebersamaan dan kerjasama. Beberapa pendapat umum ahli hukum Islam, bahwa penerimaan asuransi diuraikan sebagai berikut:

a. Bahwa semangat kerjasama akan menyebabkan kebaikan bersama;

b. Bantuan yang diberikan kepada mereka yang membutuhkan melalui kontribusi;

c. Bahwa sumbangan dari sejumlah kecil dimaksudkan untuk membagi kerugian dan menyebar kewajiban.

d. bahwa semua unsur ketidakpastian, gharar dan maysir akan dihilangkan melalui kontribusi dan kompensasi yang ditawarkan;

e. bahwa tidak ada mengambil keuntungan dari yang lain pada biaya individu lain, yaitu skema yang adil untuk semua. ${ }^{21}$

${ }^{21}$ Yusof M. F., Takaful Sistem Insurans Islam, (Kuala Lumpur: Utusan Publications and Distributors, 1996), 9-18., dalam Mohd Shril Matsawali, et.al, A Study on Takaful and 
Usaha perasuransian syariah dengan tujuan kepada nilai-nilai kebaikan dan saling tolong menolong satu dengan yang lainnya sebagai upaya untuk menjalankan perintah Allah dan sebagai objektifikasi dari kewajiban umat Islam untuk berbagai diantara sesama umat Islam.

\section{Kesimpulan}

Asuransi syariah merupakan prodak dengan mendasarkan

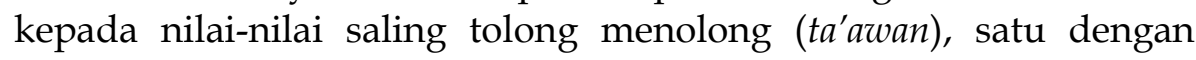
yang lainnya dalam kerangka kebiakan. Sebagai prinsip dasar saling tolong menolong, maka diperlukan aturan yang mengatur konsep tolong menolong yang terorganisir dalam bentuk corporatin sebagai perkembangan dari masyarakat modern. Di Indonesia melalui UU No. 40 Tahun 2014 tentang Perasuransian telah memberikan payung hukum bagi asuransi syariah, tetapi pada aspek lainnya, pengaturan asuransi syariah di Indonesia masih terintegrasi dalam ketentuan asuransi konvensional, oleh karena itu diperlukan aturan yang bersifat khusus yang mengatur terhadap asuransi syariah.

Persepektif hukum Islam, otensitas asuransi syariah diperlukan dengan memperkuat seluruh prodak-prodak asuransi syariah agar sesuai dengan ketentuan syariah, oleh karena itu, peran Dewan Syariah Nasional sebagai lembaga yang menangani bidang muamalah Islam di Indonesia, menjadi bagian penting dalam menjalankan bisnis asuransi berbasis asuransi syariah yang ada di Indonesia dengan melakukan pengawasan melalui Dewan Pengawas Syariah sebagaimana ditentukan dalam Fatwa Dewan Syariah Nasional (DSN) No: 21/DSN-MUI/X/2001 Tentang Pedoman Umum Asuransi Syari'ah

\section{DAFTAR PUSTAKA}

\section{Al-Qur'an}

Ali, Mohammad Daud, Hukum Islam, Pengantar Ilmu Hukum dan Tata Hukum Islam di Indonesia, Jakarta: Rajawali Pres, 2014.

Conventional Insurance Preferences: The Case of Brunei, International Journal of Business and Social Science, (Vol. 3 No. 22 , Special Issue - November 2012), 165. 
Djazuli, H. A., Kaidah-Kaidah Fikih, Kaidah-Kaidah Hukum Islam dalam Menyelesaikan Masalah-Masalah yang Praktis, Jakarta: Kencana Prenadamedia Group, 2006.

Fatwa Dewan Sayariah Nasioanl No. 21/DSN-MUI/X/2001 Tentang Pedoman Umum Asuransi Syari'ah.

Ghazaly, Abdul Rahman, et. al. Figh Muamalat, Jakarta: Kencana Prenadan Media Group, 2010.

Hamid, Mohamad Abdul, et. al. The Ownership of Islamic Insurance (Takâful) in Malaysia, International Journal of Advances in Management and Economics, Nov.-Dec. 2013, Vol.2, Issue 6.

Hussain, Mher Mushtaq dan Ahmad Tisman Pasha, Conceptual And Operational Differences Between General Takâful And Conventional Insurance, Australian Journal of Business and Management Research Vol.1 No.8, November-2011.

Koto, Alaiddin, Filsafat Hukum Islam, Jakarta: Rajawali Pres, 2013.

Muhaimin, Abdul Wahab Abd., Aktualisasi Syariah Dan Fikih Dalam Menyelesaikan Pelbagai Persoalan Hukum, Jurnal Ahkam: Vol. XV, No. 2, Juli 2015.

Mardani, Hukum Bisnis Syariah, Jakarta: Kencana Prenadamedia, 2014.

Matsawali, Mohd Shril, et.al, A Study on Takâful and Conventional Insurance Preferences: The Case of Brunei, International Journal of Business and Social Science, Vol. 3 No. 22, Special Issue November 2012.

Muhammad, Abdulkadir, Hukum Asuransi Indonesia, Cetakan Keempat, Bandung: Citra Aditya Bakti, 2006.

Manan, Abdul, Reformasi Hukum Islam di Indonesia, Jakarta, Rajawali Press: 2005.

Prakoso, Djoko, Hukum Asuransi Indonesia, Jakarta: Rineka Cipta, 2004.

Rozi, Achmad Bahrur, Penerapan Syari'ah Di Negara Modern (Analisis Ijtihad Pemikiran Abdullahi Ahmed An-Na'im), Jurnal Al-Ihkam, Vol.10 No.2 Desember 2015.

Republik Indonesia, Undang-Undang No. 40 Tahun 2014 Tentang Perasuransian.

Rasjid, Sulaiman, Figh Islam, Cet Ke-39, Bandung: Sinar Baru Algesindo, 2006.

Sumanto, Agus Edi, et.al. Solusi Asuransi, Lebih Indah dengan Syariah, Bandung: Salamadani, 2009. 
Salim, Abbas, Asuransi dan Manajemen Risiko, Jakarta: Rajawali Press, 2005.

Zainuddin, Suria dan Izyan Nadiah Md Noh, An overview of the emergence of Takâful: An Islamic type of insurance policy, International Journal of Business and Economics Research 2013, 2 (5).

http://repository.um.edu.my/31924/1/10.11648.j.ijber.2013020

5.13.pdf. Diakses pada tanggal 12 September 2016. 